\title{
The Effect of Co-Branding Strategy Elements on Consumer Attitude and Purchase Intention: A Study in Indonesia
}

\author{
Rafiati Kania ${ }^{1 *}$, Kuntihapsari Sri Sukoyo ${ }^{2}$, Nono Wibisono $^{3}$ \\ 1,2,3 Marketing Department, Politeknik Negeri Bandung \\ Correspondence: E-mail: rafiati.kania@polban.ac.id
}

\begin{abstract}
:
According to brand alliance literature, the compatibility of brand characteristics in co-branded products will raise consumer positive attitudes and purchase intention. Previous research has explored the co-branding strategy between the same sector or complement product character from different sector. However, little research has been conducted on the exploration of the co-branding strategy in a different sector with less complement character. This study seeks to construct the value of co-branding strategy of influencing female consumer attitude as well as its purchase intention. It relates to the less-known Indonesian cosmetics brand who invite well-known food brands to create blended characteristics of cosmetic products. Three co-branded products namely Mizzu Cosmetics $x$ Khong Guan Biscuits, Dear Me Beauty $x$ Yupi, Dear Me Beauty $x$ Sasa, and Dear Me Beauty $x$ Nissin as the objects of this research. A total of 358 questionnaires were distributed to female cosmetic consumers aged between 19-41. The proposed research model has been tested using PLS-SEM. The findings highlight prior attitudes toward host brands that have weak influence attitude toward co-branded products. However, the brand fit could mediate prior attitude toward host brand in influencing attitude toward co-branded product. By mediating the roles of brand fit, the attitude toward co-brand and post-attitude toward host brand show important value in the element of consumer attitude and purchase intention. A well-known and suitable co-branding partner is needed to give exposure to the cobranded product and provide a spill-over effect for the host brands. This study contributes to add spill-over effect phenomenon in brand alliance literature.
\end{abstract}

Keywords:

Co-branding, brand alliances, consumer attitude, purchase intention, Indonesia

\section{ARTICLE INFO}

Article History:

Received 03 July 2021

Revised 24 Aug 2021

Accepted 10 Sept 2021

Available online 27 Sept 2021 



\section{INTRODUCTION}

The growth of the cosmetics industry in 2019 has increased by $9 \%$ compared to the previous year which only reached $7.3 \%$. This increase is supported by the trend of Indonesian people who are gradually aware on the importance of physical appearance as a primary need that triggered to a high demand for beauty products (Kemenperin, 2019). Cosmetic and foodbeverage products are categorized as competition-driven industries that drive Fast-Moving Consumer Goods (FMCG) (Oraman, Azabagaoglu, \& Inan, 2011). According to a survey conducted by McKinsey Company in 2018, millennial consumers tend to look for things of value in products, so brand building activities and mass-market product innovation are a form of competitive advantage in FMCG (Kelly, Kopka, Küpper, \& Moulton, 2018). In addition, the market landscape of FMCG is highly competitive. Therefore, companies need an effective strategy to expand their market share and consumers. One strategy that is proven to be able to expand market share is co-branding (Helmig, Huber, \& Leeflang, 2008).

Over the past three years, the trend of co-branding has emerged cosmetics industry. The point of uniqueness lies in cosmetic brands (as a less-known brand or new brand) versus the invited brands from different sectors who are notably well-known as a brand who has huge market share. The result of the collaboration is a cosmetic product where invited brand elements are incorporated with cosmetic elements product. The application of an incorporated element of invited brands into cosmetic products as host brand have been applied in Korean cosmetics brand, for example Tony Moly which was founded in 2006. It is a brand who invite Samyang, a kind of instant noodles founded in 1961, to collaborate in producing a co-branded product where the packaging of cosmetics comes from Samyang instant noodles characters (Trend, 2018). In Indonesian context, co-branding strategy applies when less known or newly cosmetic brand invites food brands which are well-known for its huge market share. There are Mizzu Cosmetic, founded in 2012, which collaborates with Khong Guan Biscuits which was found in 1947. These brands produce cosmetic products where the packaging resembles Khong Guan Biscuits and Dear Me Beauty, a newly brand launched in 2017. These brands invited three food brands: Yupi, founded in 1996; Sasa, founded in 1973; and Nissin Wafer, founded in 1967 where the elements of packaging, smell, and colour are incorporated in co-branded lipstick products. According to Charry \& Demoulin (2014), the identity of invited brands also enriched co-branded products. Moreover, the compatibility of both brands as brands alliance can improve the product evaluation into consumer positive attitude (Thompson \& Strutton, 2012) and also as part of the key to get cobranded success (Thompson \& Strutton, 2012; Xiao \& Lee, 2014). Consumer attitude regarding co-branded product lies in its functionality, added value, and host brand name who invited the other brand (Charry \& Demoulin, 2014). Hence, understanding consumer attitude and purchase intention seem important due to tight competition in the cosmetics industry.

Collaboration between less-known and well-known brand will affect the results of cobranded products and can lead consumers to make less-known brands as a preference (Vaidyanathan \& Aggarwal, 2000). For companies, the benefit of using co-branding is to increase company revenue, to expand new market share, as well as to improve the company's image and credibility (Chang, 2009). Prior research conducted by Charry and Demoulin (2014) focused on consumer purchase intention toward co-branding between food products (vegetable soup and cream cheese to check whether this collaboration could generate an 
intention to purchase and give a spill-over effect for the less-known brand. Three potentially results are adopted by this study as an avenue to uncover how co-branding from different sectors works to influence attitude as well as purchase intention. First, co-branding strategies can give a positive impact on host brands before collaboration as well as subsequent attitudes for host brands. Second, positive consumer attitude for a less-known brand that invites wellknown brand if there are mediating functions of brand fit to mediate prior attitude toward both brands before the collaboration into the attitude toward a co-branded product. Third, the spill-over effect of a less-known brand that invites a well-known brand also means that less-known brand gets more positive evaluation brands after collaborating with well-known brands.

Since the food brand is more familiar, it will affect the popularity of co-branded products which gives a spill-over effect on the host brands as the less-known brand. This study particularly improves understanding on consumer purchase intention toward co-branded products from the cosmetic brand as a less-known brand, which invites a well-known food brand to create co-branded products by following these research questions:

1. is the prior attitude of both brands influence subsequent attitudes toward co-branded products as well as host brands (less-known brands)?

2. is brand fit works to mediate the prior attitude of both brands and attitude toward co-branded products?

3. is attitude toward co-branded products works to mediate brand fit into the attitude toward host brands (less-known brands)?

4. is attitude toward co-branded products and host brands influence purchase intention?

\section{LITERATURE REVIEW}

\subsection{Co-branding: an overview and proposed}

Co-branding, sometimes referred to as brand alliance, is a comprehensive term to revive existing brands, to reach unreached market segments, and to do brand extension strategies (Rao, Qu, \& Ruekert, 1999). Yip (2004) emphasis companies that do brand alliance would increase more profits, improve brand image, and strengthen the competitiveness. Cobranding is one of the brand alliance strategies that has been a significant concern for researchers in recent years (Helmig et al., 2008; Thompson \& Strutton, 2012). Helmig et al (2008) discuss that co-branding strategy is being equated with the brand extension due to the same purposes and gaining a broader market. Co-branding strategy has a positive impact (spill-over effect) for host brands, as a less-known brand, as it will get more positive consumer perceptions after collaborating with the stronger brands as invited brands (Simonin \& Ruth, 1998).

In general, co-branding is a strategy carried out by two brands to create a new product that combines the characteristics of both brands (Chang, 2009). In another word, co-branding is a form of cooperation between two or more marketable items that connect representation of the brands, including product brand names, corporate brand names, and product design (Bengtsson \& Servais, 2005; Washburn, Till, \& Priluck, 2000). The purpose of using a cobranding strategy is to survive in market desires that change very fast (Voss \& Mohan, 2016). The strategy has been used in various industrial sectors. For instance, in the food product, 
there was a collaboration between Betty Cocker cake and Hershey chocolate sauce. While in the field of technology, Apple Watch collaborates with Nike which notably expands the customer segment of the Apple Watch into sport-enthusiast consumers. In the same way, $\mathrm{HnM}$, as a fast-fashion company, has collaborated with luxury brand designers which expand the product into luxury yet limited edition (Böger, Kottemann, \& Decker, 2018). The application of different brand sectors has been applied between Reebok (sports outfits) and Pepsi (soft drinks) to do joint sales promotion which no combined product exists (Helmig et al., 2008).

Previous researches have been invoked to explain and to predict consumer purchase intention toward the co-branded product. The co-branded model is depicted in Figure 1, therefore, is improvised from two previous studies. First, Charry and Demoulin (2014) study on mediating roles of attitude toward co-branded product on brand fit and purchase intention consumer attitude toward purchase intention and brand fit mediating roles toward the attitude toward the co-branded product. Second, Thompson and Strutton (2012) study on brand fit as mediator variables between attitude toward host brands and co-branded evaluation. This study will enrich the perspective on post attitude toward host brands as the mediator between attitude toward co-branded and purchase intention. The enrichment is inspired by spill-over effect perception developed by Rodrigue and Biswas (2004) who emphasize positive evaluation on host brands after the brand collaborates. This study will enrich the co-branding perspective on how the spill-over effect influences purchase intention. Hence, the novelty of this study lies in three mediating elements, namely brand fit, attitude toward co-branded, and post-attitude toward host brands. Each hypothesis is depicted in Figure 1 . This path model summarizes all proposed relationships which are examined by this study in the next section.

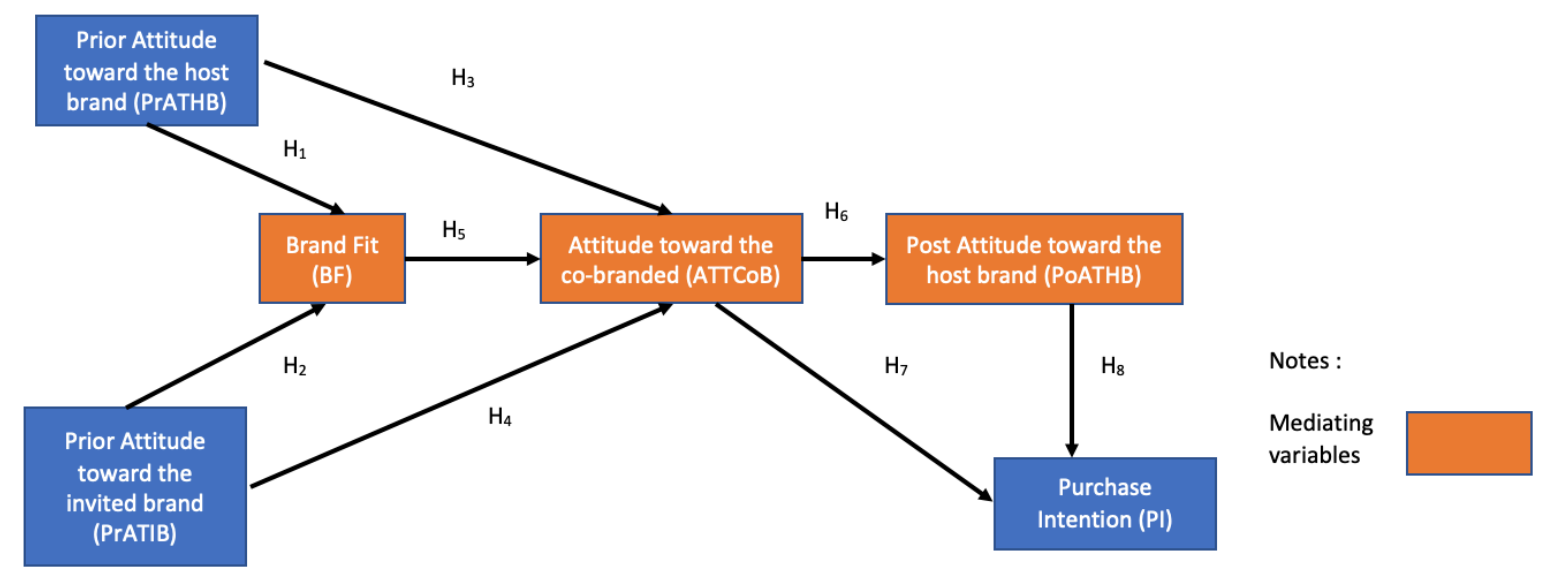

Figure 1 Co-Branding Model

\subsection{The influence of prior attitude toward host brands and invited brands}

When well-known brands collaborate with less-known brands, consumers will associate the well-known brands with the partner companies (Besharat, 2010). Consumers will give a beneficial effect on less familiar brands when they work together and will form high equity in the minds of consumers. Moreover, consumer perception of fit is obtained from the suitability 
in collaboration. Suitability is defined as how far the image of both brands is suitable for the co-branded product (DelVecchio \& Smith, 2005; Simonin \& Ruth, 1998). DelVecchio \& Smith (2005) revealed that suitability of host and invited brands before collaboration is the main element to avoid negative consumer perceptions of co-branded products. Accordingly, some of the following hypotheses are developed:

$\mathrm{H}_{1}$ : Prior attitude toward the host brand should positively influence brand fit

$\mathrm{H}_{2}$ : Prior attitude toward the invited brands should positively influence brand fit

Each brand has a specific purpose in co-branding strategy, including transferring brand image and creating new products related to host brands (Cooke \& Ryan, 2000). Washburn et al. (2000) state that less-known brands get the most benefit through co-branding, one of which is popularity. In this study, brand cosmetics seek benefits in the form of unique new product innovations that comes from inviting well-known food brands. Hence, consumer attitude regarding host-brand effort to invite well-known brands might influence co-branded product evaluation.

The influence of the invited brands' familiar or salient name has a significant effect on consumer evaluation of co-branded products. Besides, another influence of a more salient brand will make the consumer feels easier to buy the product. This will affect consumers' attitudes toward co-branded products (Charry \& Demoulin, 2014). Consumer evaluation of co-branded products is influenced by consumer attitude toward core brands or more wellknown brands (Dickinson \& Heath, 2006). On the contrary, Guillet and Tasci (2010) argue that high familiarity does not ensure co-branding success. The most beneficial effect of collaborating with a well-known brand here referred to the invited brands which can make promotional easier owing to the invited brands which already has equity in the minds of consumers. Thus, consumers can easily recognize this co-branded product (Helmig et al., 2008). Accordingly, some of the following hypotheses are developed:

$\mathrm{H}_{3}$ : Prior attitude toward the invited brands should positively influence attitude toward the co-branded product

$\mathrm{H}_{4}$ : Prior attitude toward the invited brands should positively influence attitude toward the co-branded product

\subsection{The mediator of Consumer Perceived of Fit (Brand Fit)}

The most important thing before collaboration is choosing the right partner (Charry \& Demoulin, 2014). It is due to consumers' decision-making in co-branding which is influenced by consumer perception of fit (Lin, 2013). There are two types of fit, namely brand fit and product fit. Brand fit is defined as an association between two partnering brands in consumers' minds (Lafferty, Goldsmith, \& Hult, 2004). On the other hand, product fit refers to the compatibility of functional product level in consumer's perception (Simonin \& Ruth, 1998). Thompson and Strutton (2012) revealed that positive results on co-branded products are influenced by a high level of compatibility between host brand and invited brand. Accordingly, some of the following hypotheses are developed:

$\mathrm{H}_{1 \mathrm{a}}$ : Brand fit mediates prior attitude toward the host brand and attitude toward co-branded $\mathrm{H}_{2 \mathrm{a}}$ : Brand fit mediates prior attitude toward the invited brand and attitude toward cobranded 
On the other hand, mistakes in choosing partners can lead to disintegrate brand identity. If consumers evaluate co-branded products from their compatibility, their positive attitude toward host brands will automatically influence consumers' positive evaluations of cobranded products (Dickinson \& Heath, 2006; Simonin \& Ruth, 1998; Washburn et al., 2000). However, a good match does not necessarily affect a consumer's intention to purchase (Till \& Busler, 2000). This hypothesis was created from the above discussion:

$\mathrm{H}_{5}$ : Brand fit should positively influence attitude toward the co-branded product

\subsection{The mediator of Attitude toward co-branded product}

Simonin and Ruth (1998) state that consumers' positive assessment of a brand after the alliance is the same as the consumer's attitude toward the two brands before the alliance. This positive evaluation is ultimately the same as subsequent evaluation. This attitude stability is a human basic psychological (Ajzen and Fishbein, 2000). Previous studies related to consumer attitude toward co-branding found factors that can influence post attitude toward the host brands, such as the familiarity of each brand (Kumar, 2005; Simonin \& Ruth, 1998), brand reputation, brand equity (Vaidyanathan \& Aggarwal, 2000; Washburn et al., 2000), the consumer experience of brand quality (Rao et al., 1999; Voss \& Gammoh, 2004), and loyalty toward each parent brands (Swaminathan, Reddy, \& Dommer, 2012). Accordingly, some of the following hypotheses are developed:

$\mathrm{H}_{3 \mathrm{a}}$ : Attitude toward co-branded mediates prior attitude toward the host brand and postattitude toward host brand

$\mathrm{H}_{4 \mathrm{a}}$ : Attitude toward co-branded mediates prior attitude toward the invited brand and postattitude toward host brand

Brand fit is often used to verify the strong influence of a brand $d$ in co-branding strategy. Perceptions and symbols from high equity brands can be utilized on co-branding (Vaidyanathan \& Aggarwal, 2000). The aim is to see how much influence the invited brand has on this strategy. The more popular brand will have a more prominent role in consumer attitude toward the co-branded product (Simonin \& Ruth, 1998). Thus, the attitude toward co-branded products depends on the influence of more salient brands. Good match on co-branding also has a positive evaluation of co-branded products as well as lead to consumer purchase intention (Bouten, Snelders, \& Hultink, 2011; Helmig et al., 2008; Simonin \& Ruth, 1998; Washburn et al., 2000). Accordingly, some of the following hypotheses are developed :

$\mathrm{H}_{5 \mathrm{a}}$ : Attitude toward co-branded mediates brand fit and post-attitude toward host brand

$\mathrm{H}_{6 a}$ : Attitude toward co-branded product mediates prior attitude toward the invited brand and post attitude toward the host brand

$\mathrm{H}_{6}$ : Attitude toward the co-branded product should positively influence post attitude toward the host brands

Attitude toward brand becomes an essential element in consumer decision making. Positive consumer evaluation of a brand will be leading to consumers' purchase intention (Yasid, Farhan, \& Andriansyah, 2016). This will have a significant positive effect on the cobranded product. In the context of those statements, can be hypothesized as follow:

$\mathrm{H}_{7}$ : Attitude toward the co-branded product should positively influence consumer purchase intention 


\subsection{The mediator of post attitude toward host brand}

Subsequent consumer attitude toward the host brands is determined since consumers evaluate the co-branded product to be suitable (Thompson \& Strutton, 2012). The cobranding strategy is considered an effective and profitable strategy because it provides additional value for both brands and increases positive consumer perceptions for the parent brands (Charry \& Demoulin, 2014). The co-branding strategy has a positive impact (spill-over effect) for both brands, considered as a less-familiar brand will get more positive perceptions than the more familiar brand after collaboration (Rodrigue \& Biswas, 2004; Simonin \& Ruth, 1998).

Intention to purchase is defined as a consumer's alternative consideration of a product that is influenced by consumer decision-making (Ashton \& Scott, 2011). Further, several studies conducted by Carrillat, Lafferty, \& Harris (2005) and Keller (1993) stated that two factors that significantly influence purchase intention are brand familiarity and brand knowledge. Consumer knowledge of a brand will produce a positive consumer attitude that will later lead to purchase intention (Salim Khraim, 2011). When consumers know the brand well, this will lead to higher buying investment (Samadi \& Nejadi, 2009). Accordingly, some of the following hypotheses are developed:

$\mathrm{H}_{7 \mathrm{a}}$ : Post Attitude toward host brand mediates attitude toward co-branded and purchase intention

$\mathrm{H}_{8}$ : Post attitude toward host brands should positively influence purchase intention.

\section{METHODS}

\subsection{Data Collection and Samples}

This study used the questionnaire survey to verify the hypotheses and research framework. The subjects were Indonesian female consumers who recognize co-branded cosmetics products, namely Mizzu Cosmetics x Khong Guan Biscuits, Dear Me Beauty x Yupi, Dear Me Beauty x Sasa, and Dear Me Beauty x Nissin. From February 2020 to May 2020, questionnaires were distributed online through social media and beauty community platforms. A total of 358 questionnaires about purchase intention toward co-branded products were obtained. According to Hair et al (2012), who studies assessment techniques in PLS-SEM for marketing research, the rule of thumb for counting minimum sample size is "ten times rule" through ten times the maximum number of formative indicators per construct and number of path relationship directed. The research framework of this study consists of 18 indicators and 8 path relationship; hence, minimum samples size is $10 \times 26=260$ samples. To be concluded, 358 respondents were appropriate for further analysis.

\subsection{Definition and measurement of variables}

The questionnaire items in this study were measured on a five-point Likert Scale where 1 indicates strongly disagree and 5 indicates strongly agree. The definitions of variables were defined as follows. First, this study adapts Charry and Demoulin (2014) for prior attitude variables (both toward host and invited brands), attitude toward the co-branded product, and post-attitude toward the host brands. Charry and Demoulin (2014) study children's attitudes toward the co-branded product. Prior attitudes measure consumer evaluation about the brand before the collaboration. The element of good branding, favourite brand, and attractive 
brand are indicators of prior attitude. The element of uniqueness, loveable product and attractiveness of branding concepts are the indicators of attitude toward the co-branded product. Post attitude toward host brand measures subsequent consumer attitude in evaluating brand initiatives that confirm attractiveness, inspiration, and loveable aspects. Second, this study adopts the brand fit perspective from Thompson and Strutton (2012) who observe perceptions of perceptual fit between fashion and food industry. Brand fit evaluates on how good collaboration strategy in terms of correlation, invited brands influence, and acceptable perspectives. Third, this study adapts Salim Khraim (2011) for purchasing intention which confirms desirability to purchase, namely buying action, using action, and collecting action.

\subsection{Data Analysis: partial least square path modeling and mediation analysis}

After the data has been collected and considered as the primary data, data analysis is carried out to process the raw data into data that is ready to be used for hypothesis testing. At this stage, researchers used the IBM SPSS Statistics 22 software for descriptive analysis of the respondent's profile. Further, the validity test and reliability of the construct used variance-based partial least square (PLS). Evaluation of structural models and hypotheses testing that have been formulated using the same software named SmartPLS (Hair et al., 2013). Besides, SmartPLS is used for measuring small samples and providing more complex research models (Chin, 2010).

SEM-PLS is commonly used in applied science research, such as consumer knowledge and marketing (Vicente-Molina et al., 2018). The requirements used to avoid biased data in quantitative research are to carry out construct validity tests and instrument reliability tests which are commonly called measurement models or outer model testing. The measurement model is the process of examining the relationship between indicators and variables or how well research indicators can explain and reflect latent variables. In this study, researchers conducted a validity and reliability test through convergent validity and discriminant validity, while reliability using the indicator test of reliability and internal consistency reliability. To test convergent validity, factor loading and average variance extracted (AVE) were used. The construct is said to be valid if the loading factor value must exceed 0.4 while the value of AVE should be higher than 0,5 (Joe F. Hair, Ringle, \& Sarstedt, 2011). To ensure the internal consistency reliability, Joe $\mathrm{F}$ Hair et al (2012) recommended that the composite reliability value of each first-order reflectively measured construct has to be 0.70 and above. The next step is measuring the discriminant validity of Fornell-Larcker criterion with the requirement that all latent variables have more variance with the variable itself than other constructions in the same model (Fornell \& Larcker, 1981).

After the data is sure to meet the criteria in measuring validity and reliability, the next step is analysing the structural model by using SmartPLS 3.0. This step aims to test the predictive ability of the model and the predetermined hypotheses relationships (Joseph F. Hair et al., 2013). Data were analysed by testing through Goodness-of-Fit, Coefficient Determination $\left(R^{2}\right)$, Predictive Relevance $\left(Q^{2}\right)$, Path Coefficient, and t-testing with bootstrapping analysis. The purpose of the Goodness of Fit testing in this study is used to determine the suitability and feasibility of the research model. If the research model does not match the data, the estimated results are meaningless, and the conclusions to be drawn are 
questionable. To test how well the research model predicts the data, a coefficient of determination is used. Coefficient determinants analysis is used to determine the simultaneous effect of exogenous on endogenous variables. This analysis aims to assess the predictive level of the research model. The $Q^{2}$ value is obtained through the Blindfolding analysis (Chin, Peterson, \& Brown, 2008). The required $Q^{2}$ value according to the criteria should be more than 0 since it is the cut-off value (Joe F Hair et al., 2012). This method is used to test the significance of the path coefficient and test the hypothesis by using 5000 bootstrap samples (Henseler, Ringle, \& Sarstedt, 2015).

According to our research model, three mediating variables contribute to mediate, namely prior attitude, brand fit, the attitude of co-branded, post-attitude. In testing the mediation effect, the Sobel test is used as the causal-step method developed by Stone \& Sobel (1990). According to the Sobel test, estimation of indirect effects and bootstrapping analysis appears robust in the population which are greater than 200 samples (Stone \& Sobel, 1990). Our research model involves multiple mediators. Bootstrapping and indirect effect analysis are claimed as mediating variable effects measurement (Bollen \& Stine, 1990; Zhao, Lynch, \& Chen, 2010). Moreover, bootstrapping appears more accurate in the Sobel test (Taylor, MacKinnon, \& Tein, 2008). Herein, we perform bootstrapping at a 95\% confidence interval with 5000 samples

\section{RESULTS}

\subsection{Respondent Profiles}

The brief demographics were shown in table 2 . In age aspects, $78,8 \%$ of respondents were generation $Z$ female (born in 1997-2002) and almost half of respondents were generation $Y$ (millennials). In terms of occupation, $57,7 \%$ of respondents are students and $26 \%$ are employees. Other occupations include entrepreneur, freelancer, and housewife. The level of education is high-school degree $(49,4 \%)$ and undergraduate $(40 \%)$. In consumption pattern, around half of respondents switch cosmetics product less than three times per year $(51,1 \%)$ and $33,5 \%$ switch cosmetics product for three up to five times (33,5\%).

Table 2. Respondent Profiles

\begin{tabular}{|c|c|c|c|c|c|}
\hline \multicolumn{6}{|c|}{ Respondent Profiles } \\
\hline Year of Birth & Frequency & $\%$ & $\begin{array}{l}\text { Frequency of switching } \\
\text { cosmetics product per } \\
\text { year }\end{array}$ & Frequency & $\%$ \\
\hline 1997-2002 (age 19-24) & 282 & 78,8 & $<3$ times & 183 & 51,1 \\
\hline 1991-1996 (age $25-30$ ) & 49 & 13,7 & 3-5 times & 120 & 33,5 \\
\hline $1981-1990$ (age $31-41$ ) & 27 & 7,5 & $>5$ times & 55 & 15,4 \\
\hline Occupation & Frequency & $\%$ & Level of Education & Frequency & $\%$ \\
\hline Students & 206 & 57,5 & High-school & 177 & 49,4 \\
\hline Employee & 96 & 26,8 & Undergraduate & 146 & 40 \\
\hline Other & 56 & 15,7 & Master or doctoral & 35 & 10,6 \\
\hline
\end{tabular}




\subsection{Empirical Results of Measurement Model: Reliability and Validity}

This study referred to the previous studies to design the questionnaire items and employed pre-tests for the questionnaire revisions. Therefore, the measurement of this study was acceptable in content validity. In the attempt to reach the statistical power of the research model, this study has to confirm how well the indicators in explaining the latent variables with the reflective model. Joe F Hair, et al., (2012) suggest indicator reliability, internal consistency reliability, convergent validity, and discriminant validity measure outer model (measurement model evaluation). The factor analysis of the six latent variables was shown in Table 2. First, factor loading value indicates indicator reliability where the value must be greater than 0.50 (Hulland, 1999) for an acceptable minimum value or 0.70 to reach statistical power (Fornell \& Larcker, 1981; Joe F Hair et al., 2012). Almost all factor loading value of each latent variables was greater than 0.7 and only one indicator in brand fit variable was greater than 0.6 . Second, the minimum requirement of composite reliability should be greater than 0.7 to confirm that indicators are equally reliable (Joe F. Hair et al., 2011). In relation to reliability, the composite reliability of each construct was above 0.7 . Therefore, it is indicated as good internal consistency reliability.

Table 3. Factor Analysis Result: Loading, Cronbach Alpha, CR, AVE

\begin{tabular}{|c|c|c|c|}
\hline Construction (Mean; Standard Deviation) & Loading & CR & AVE \\
\hline Prior attitude Toward the Host brands $(3,724 ; 0,761)$ & & 0,898 & 0,747 \\
\hline this brand is interesting & 0,849 & & \\
\hline I like this brand & 0,886 & & \\
\hline This brand has a good brand image & 0,857 & & \\
\hline Prior attitude Toward the Invited brands $(3,877$; & & & \\
\hline 0,777$)$ & & 0,898 & 0,745 \\
\hline This brand is interesting & 0,860 & & \\
\hline I like this brand & 0,902 & & \\
\hline This brand has a good brand image & 0,826 & & \\
\hline Fit $(3,703 ; 0,744)$ & & 0,800 & 0,576 \\
\hline I can accept this collaboration & 0,848 & & \\
\hline $\begin{array}{l}\text { I think the invited brands has influenced the host } \\
\text { brands }\end{array}$ & 0,623 & & \\
\hline Both are having a collaboration & 0,788 & & \\
\hline $\begin{array}{l}\text { Attitude Toward The Co-Branded Product }(4,089 ; \\
0,910)\end{array}$ & & 0,942 & 0,844 \\
\hline Co-branded product is unique & 0,935 & & \\
\hline Co-branded products are preferred & 0,909 & & \\
\hline The co-branded product looks more attractive & 0,913 & & \\
\hline Post attitude Toward the Host brands $(3,769 ; 0,895)$ & & 0,898 & 0,747 \\
\hline Host brands look more attractive after collaboration & 0,900 & & \\
\hline I like host brands & 0,902 & & \\
\hline Other brands should apply this & 0,786 & & \\
\hline Purchase Intention $(3,85 ; 0,944)$ & & 0,954 & 0,873 \\
\hline I am interested to buy & 0,936 & & \\
\hline
\end{tabular}


I am interested to use $\quad 0,940$

I am desire to collect $\quad 0,927$

Regarding to validity, there are two aspects to confirm the validity of latent variables construct. First, if the average variance extracted (AVE) of latent variables was greater than 0.5 , it means that the convergent validity for the construct has been reached. As shown in Table 3, the AVE of all constructs was greater than 0.5. Therefore, these results supported the convergent validity of the measurement (Fornell, C., \& Larcker, 1981). Second, this study applied Fornell and Larcker's measure of AVE to access the discriminative validity of the measurement (see table 4). Through the method proposed by Fornell \& Larcker (1981), the assumption to what extent to which each construction is differentiated is indicated by the value of the square root of Average Variance Explained (AVE) of each latent variable is greater than the shared variance between other latent variables. In other words, the diagonal bold values (as remarked in Table 4 ) is greater than other variables value in the same row as well as column.

Table 4. Discriminant Validity Result: Fornell-Lacker Criterion

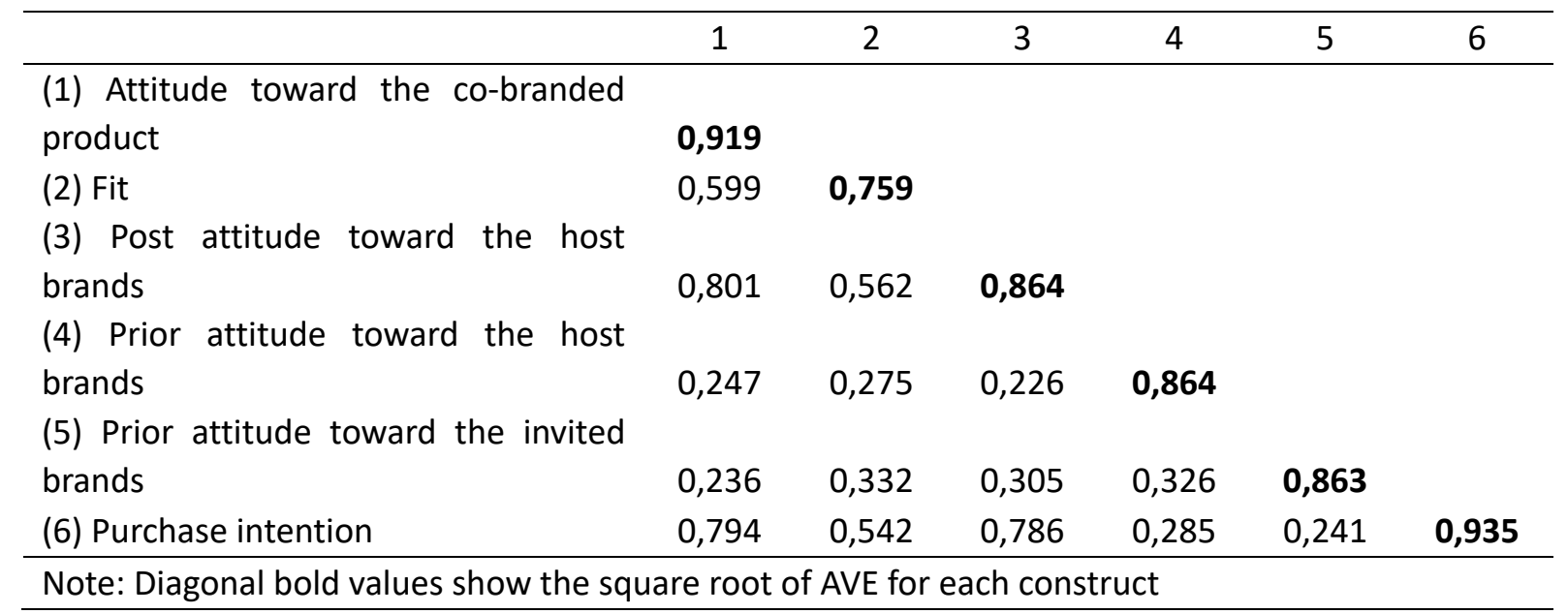




\subsection{Empirical Results of Structural Model}

Measurement of the coefficients of determination $\left(R^{2}\right)$ is performed to assess model fitness, as suggested by (Joe F. Hair et al., 2011; Joseph F. Hair et al., 2013). Goodness-of-Fit (GoF) was calculated to determine the overall quality of the research model (Tenenhaus, Vinzi, Chatelin, \& Lauro, 2005). Predictive relevance $\left(Q^{2}\right)$ with a value above 0 is indicative of predictive relevance as of model compatibility (Joseph F. Hair et al., 2013). $R^{2}$, GoF, and $Q^{2}$ values are reported in Table 5. Joe F. Hair et al (2011) classify GoF degree into three categories: low (GoF>0.10), moderate (GoF>0.25), and high (GoF>0.36). Since the value of GoF is 0.590, the overall quality of the research model is categorized as high. Regarding predictive relevance $\left(Q^{2}\right)$, each latent variable considered as an endogenous variable has a value above 0 . Hence, each variable has a satisfactory predictive relevance.

Table 5. The goodness of Fit Index

\begin{tabular}{lccc}
\hline \multicolumn{1}{c}{ Latent Variables } & AVE & $\mathbf{R}^{\mathbf{2}}$ & $\mathbf{Q}^{\mathbf{2}}$ \\
\hline $\begin{array}{l}\text { Prior attitudes toward the host brands } \\
\text { (PrATHB) }\end{array}$ & 0,747 & - & - \\
$\begin{array}{l}\text { Prior attitudes toward the invited } \\
\text { brands (PrATIB) }\end{array}$ & 0,745 & - & - \\
$\begin{array}{l}\text { Brand Fit (BF) } \\
\text { Attitude toward the co-branded }\end{array}$ & 0,576 & 0,141 & 0,077 \\
product (ATTCoB & 0,844 & 0,367 & 0,301 \\
$\begin{array}{l}\text { Post attitudes toward the host brands } \\
\text { (PoAHB) }\end{array}$ & 0,747 & 0,672 & 0,462 \\
Purchase intention (PI) & 0,873 & 0,693 & 0,6 \\
\hline AVE $\times \mathrm{R}^{2}$ & & 0,348 & \\
\hline GoF $=\mathrm{V}\left(\mathrm{AVE} \times \mathrm{R}^{2}\right)$ & & $\mathbf{0 , 5 9 0}$ & \\
\hline
\end{tabular}

According to Joe F. Hair et al (2011), coefficient of determination $\left(R^{2}\right)$ is considered as a primary criterion for inner model assessment which represents the amount of variance endogenous latent variables are explained by linked variables. The value can be represented as low level $\left(R^{2}<0.3\right)$, moderate level $\left(0.3<R^{2}<0.6\right)$, and high level $\left(R^{2}>0.60\right)$. Based on Table 4 , the value of $R^{2}$ values indicates:

1. Prior toward the host brands (PrATHB) and Prior attitude toward the invited brands (PrATIB) have weak ability to explain the variability of Brand Fit

2. Brand Fit, Prior toward the host brands (PrATHB) and Prior attitude toward the invited brands (PrATIB) have moderate ability to explain the variability of Attitude toward the cobranded product (ATTCOB)

3. Attitude toward the co-branded product (ATTCOB) have a high ability to explain the variability of Post attitude toward the host brands (PoAHB)

4. Post attitude toward the host brands (POATHB) and Attitude toward the co-branded product (ATTCOB) have a high ability to explain the variability of purchase intention (PI) 


\subsection{Empirical Results of Hypothesis Testing and Mediating Effect}

Path analysis testing was conducted to determine the relationship between hypotheses that had been developed in the literature review. At this stage, the structural model is evaluated by analysing the significance and relevance of the proposed relationship, as well as to answer the second research question. Bootstrapping method is used to test the level of significance of path coefficients in the model. As suggested by Joe F. Hair et al (2011), the evaluation of the path coefficients is done through a 95\% bootstrap confidence interval using 5000 samples. Using bootstrapping analysis, we examine the direct effect for hypothesis testing (Table 6) and mediating effect for particular variables (table 7).

Table 6. Hypothesis Testing Result

\begin{tabular}{ccrrrr}
\hline \multirow{2}{*}{ Hypothesis } & \multirow{2}{*}{ Path } & \multicolumn{3}{c}{ Path Estimation (Direct } & \multirow{2}{*}{ Effect) } \\
\cline { 3 - 5 } & & $\boldsymbol{\beta}$ & t-value & P Values* & \\
\hline $\mathrm{H}_{1}$ & PrATHB $\rightarrow$ Brand fit & 0,186 & 2,854 & 0.000 & Accepted \\
$\mathrm{H}_{2}$ & PrATHB $\rightarrow$ ATTCoB & 0,084 & 1,566 & 0.180 & Rejected \\
$\mathrm{H}_{3}$ & PrATIB $\rightarrow$ Brand Fit & 0,271 & 4,843 & 0.010 & Accepted \\
$\mathrm{H}_{4}$ & PrATIB $\rightarrow$ ATTCoB & 0,020 & 0,390 & 0.000 & Accepted \\
$\mathrm{H}_{5}$ & Brand Fit $\rightarrow$ ATTCoB & 0,570 & 11,855 & 0.000 & Accepted \\
$\mathrm{H}_{6}$ & ATTCoB $\rightarrow$ PoAHB & 0,801 & 26,677 & 0.000 & Accepted \\
$\mathrm{H}_{7}$ & ATTCoB $\rightarrow$ PT & 0,457 & 5,795 & 0.030 & Accepted \\
$\mathrm{H}_{8}$ & PoAHB $\rightarrow$ PI & 0,420 & 5,232 & 0.000 & Accepted \\
\hline Note $:{ }^{*} \mathrm{p}<0.05, \mathrm{t}>1,96$ & & & & \\
\hline
\end{tabular}

This study found out that seven path hypotheses are significant while one hypothesis is not significant. The relationship between prior attitude toward host brands and attitude toward the co-branded product is not significant, hence $\mathrm{H}_{2}$ was rejected. This study also found out that both prior attitudes toward host brands as well as invited brands have a significant effect on brand fit. Hence, $\mathrm{H} 1$ and $\mathrm{H} 3$ were accepted. Only prior attitude toward invited brands has a significant effect on attitude toward co-branded products $\left(\mathrm{H}_{4}\right)$. Aside from that, the result also shows that the brand fit variable has a significant effect on attitude toward cobranded products, thus $\mathrm{H} 5$ is supported. The same is true for the relationship between attitude toward co-branded products on post-attitude toward host brands $\left(\mathrm{H}_{6}\right)$. Regarding purchase intention, both attitudes attitude branded products and post-attitude toward host brands proved a significant effect on purchase intention through $\mathrm{H}_{7}$ and $\mathrm{H}_{8}$, respectively. As has been noted, the accepted hypotheses are $\mathrm{H}_{1}, \mathrm{H}_{3}, \mathrm{H}_{4}, \mathrm{H}_{5}, \mathrm{H}_{6}, \mathrm{H}_{7}$, and $\mathrm{H}_{8}$.

Table 7. Result of mediation test

\begin{tabular}{clcccc}
\hline \multirow{2}{*}{ Hypothesis } & \multirow{2}{*}{ Path } & \multicolumn{3}{c}{ Path Estimation (Indirect Effect) } & Remarks \\
\cline { 3 - 6 } & & $\boldsymbol{\beta}$ & t-value & P Values* & \\
\hline $\mathrm{H}_{1 \mathrm{a}}$ & PrATHB $\rightarrow \mathrm{BF} \rightarrow \mathrm{ATTCOB}$ & 0,186 & 2,854 & 0.000 & Accepted \\
& & 0,271 & 4,843 & 0.000 & Accepted \\
$\mathrm{H}_{2 \mathrm{a}}$ & PrATIB $\rightarrow \mathrm{BF} \rightarrow$ ATTCOB & 0,106 & 2,777 & 0.000 & Accepted
\end{tabular}


43 | Journal of Marketing Innovation, Volume 1 Issue 1, Sept 2021 Hal 30-50

\begin{tabular}{clcccr}
$\mathrm{H}_{4 a}$ & PrATIB $\rightarrow$ ATCOB $\rightarrow$ PoATHB & 0.154 & 4,608 & 0.020 & Accepted \\
$\mathrm{H}_{5 \mathrm{~A}}$ & $\mathrm{BF} \rightarrow \mathrm{ATCOB} \rightarrow \mathrm{PoATHB}$ & 0,570 & 11,855 & 0.000 & Accepted \\
\hline $\mathrm{H}_{7 \mathrm{a}}$ & ATTCOB $\rightarrow$ PoATHB $\rightarrow \mathrm{PI}$ & 0,420 & 5,232 & 0.000 & Accepted \\
\hline Note $:{ }^{*} \mathrm{p}<0.05, \mathrm{t}>1,96$ & & & & \\
\hline
\end{tabular}

Further, Table 7 shows that the indirect effects are significant for the whole mediating variables. This study emphasis brand fit mediating effect power to confirm the insignificant effect of prior attitude toward host brands effect on attitude toward co-branded. Brand fit mediating the relationship between prior attitudes toward brands (both host and invited) and attitude toward co-branded products is significant. It reveals that brand fit is the essential factor in influencing consumer attitude toward the co-branded product. Particularly for the invited brands, this study emphasizes that brand fit expresses a stronger effect to influence attitude toward products rather than attitude toward the invited brands.

\section{DISCUSSION}

This study aims to find out how consumers perceive the co-branded product from different business sectors. Indonesian local cosmetics brands that have used this strategy are Dear Me Beauty, which has collaborated with Yupi, Sasa, and Nissin Waffer, while Mizzu Cosmetics has collaborated with Khong Guan and Fore Coffee. The results support the reliability and validity of the measurement model (table 3 and 4) for Indonesian female consumers. Moreover, the results confirm medium to high predictive power $\left(R^{2}\right)$ and predictive validity $\left(Q^{2}\right)$ of purchase intention toward co-branding strategy. As can be seen in Table 5, post-attitude toward host brands and purchase intention display substantial $R^{2}$ values $\left(R^{2}>0.60\right)$ according to Chin (2010) and Joe F Hair et al (2012)

With respect to several direct effects represented by $\mathrm{H}_{1}, \mathrm{H}_{3}$, and $\mathrm{H}_{5}$ hypotheses. Firstly, it is highlighted in Table 6 that prior attitude toward the host as well as invited brands affected the perceptual fit of co-branding strategy, where a significant direct effect on brand fit is seen $\left(\mathrm{H}_{1} \& \mathrm{H}_{3}\right)$. This study confirms female consumers ' favourable perception of both brand images contributes in constructing the fit regarding acceptable collaboration and the effect of invited brands in a proposed co-branded product. This finding enriched the study of brand extension which Thompson \& Strutton (2012) did that find out the perception on how well brand extension strategy is affected by the perceptual fit of both hosts and invited brands as was as their fit with extension product. Also, in the service sector, complementary attributes obtained from both brands affect brand fit (Ashton \& Scott, 2011; Wang et al, 2012). According to the general terms of brand fit, Aaker \& Keller (1990) argue that perceptual fit regards to what extent host and invited brands perceived complementary, substitutable in use, and image transfer of invited brands equity in making product. In the case of the brand chosen by this study, the attribute of colour and cartoon from Khong Guan and Sasa are embedded in co-branded product design which host brands products (lipstick and blush on) are embedded inside the product. Meanwhile, the attribute of colour and fragrance from Nissin and Yupi are embedded in lipsticks ingredients. It means that the perceptual fit of those brands to collaborate lies on perceived complementary and image transfer. The perspective of substitutable in use did not exist in collaboration. Therefore, perceived complementary and image transfer are brand fit characteristics in co-branding from cosmetic and food products. 
Second, with $\mathrm{H}_{5}$, we also predicted the full mediation of brand fit in the relationship between the prior attitude of both brands and attitude toward co-branding strategy $\left(\mathrm{H}_{1 \mathrm{a}}\right.$ \& $\mathrm{H}_{2 a}$ ). This study confirms the same effect as Charry \& Demoulin (2014) who study facilitating role of brand fit in children's response toward the co-branded product. The findings Tasci and Guillet (2011) study about the brand equity effect from the compatibility of restaurant and hotel brands will affect the success of a co-branded product. In this regard, consumer brand awareness and perceptual fit or compatibility are important aspects to influence the positive evaluation of co-branded products. In this case, brand cosmetics seek benefits in the form of unique new product innovations and brand familiarity which were obtained from food. The more popular the food brand is, the more popular it will effect on the popularity of co-branded products. By doing brand collaboration, we must determine partners who have good branding, attractive products, and preferred by consumers. So, a successful co-branded product can be achieved.

Third, $\mathrm{H}_{4}$ suggested a direct effect of prior attitude toward invited brands on attitude products-branded products. However, the direction of prior attitude toward host brands on attitude toward co-branded product was not significant, hence, $\mathrm{H}_{2}$ was rejected. To accepted $\mathrm{H}_{5}$ and rejected $\mathrm{H}_{2}$, the effect of prior attitude toward invited brands was substantially more important to construct the attitude toward co-branded products which eventually indirectly influences both attitudes toward host brands and purchase intention. This study contends Charry \& Demoulin (2014) who study the same business sector collaboration as well as Thompson and Strutton (2012) who study different business sector collaboration. Both studies confirm that host brands attitude and invited brands attitude strongly influence consumer attitude toward the co-branded product. The different results may result due to one parameter employed to describe variable prior attitude (both brands) that unite two indicators "this brand is awesome and this brand is friendly" from the previous study into "the brand is interesting" (see Table 3). It means that the context of cosmetic product who invited different sector such as food product, an invited brands that has good branding, interesting, and well-recognized by consumers will affect consumer evaluation on the co-branded products regarding how attractive the product is.

Fourth, $\mathrm{H}_{6}$ and $\mathrm{H}_{7}$ suggested a direct effect of attitude toward co-branded on post attitude toward host brands and purchase intention respectively. This answers the second research question. The study was done by Simonin \& Ruth (1998) also notes that there is a stable consumer attitude after seeing a brand before and after collaboration. Loyalty and consumer attitude toward brand cosmetics will remain the same after seeing these brands collaborate. Furthermore, researchers found that the relationship between attitude toward co-branded products has a positive effect on the intention to purchase. These findings are in agreement with the prior study on co-branding cream soup and cream cheese where it found attitude toward co-branded products leads to consumption intention (Charry \& Demoulin, 2014).

Fifth, this study found out the contribution of attitude toward co-branded as mediator elements toward influencing post attitude toward host brand and purchase intention. The indirect effect of Attitude toward Co-branded (ATCOB) toward two variables is as follow: post attitude toward host brands and purchase intention. Since $\mathrm{H}_{2}$ was rejected, the mediating path BF $\rightarrow$ ATCOB $\rightarrow$ PoATHB and PrATHB $\rightarrow$ ATCOB $\rightarrow$ PoATHB express more substantial (significant 0.000 in $\mathrm{P}<0.05$ ) rather than the other path which includes prior attitude (invited). 
This study emphasis that facilitating the function of brand fit will construct prior attitude from both brands (before collaborating) to construct consumer evaluation on co-branded product and will facilitate appraisal of host brands as well as intention to purchase. Regarding the significant effect on post attitude toward host brands, this study revisits Rodrigue and Biswas (2004) argument that the host brands get a spill-over effect from the collaboration. Meanwhile, Charry and Demoulin (2014) argue that consumer attitude toward host brands should be improved even though the host brands consider to be weaker appraisal rather than invited brands. Therefore, the finding emphasis that the spill-over effect within-host brands is not only express in the same sector collaboration, but also in different sector collaboration.

Finally, $\mathrm{H} 8$ suggested a direct effect of post attitude toward the host brands on purchase intention. This supports the prior research conducted by Lin (2013) in the context of cobranding hotels. The study was done by Charry and Demoulin (2014) which also shows that positive consumer attitude toward the host brands not only affects the intention to purchase the co-products, but also affects consumer intention to buy other products from the brand itself. Co-branding will help the host brands to increase their popularities. Moreover, a cobranding strategy brings a customer base which is the potential to raise brand awareness (Leuthesser, Kohli, \& Suri, 2003). Consumers tend to consider the brand as a choice when they seek cosmetics and also they will keep finding out new products from the brand. This finding emphasis consumers who have a strong perception of the host brands will still have the same perception after collaboration. Other than that, when deciding to do co-branding, the brand must be familiar among the consumers as this will lead to consumer decisionmaking behaviour. The consumer's decision-making is motivated by the consumer's experience with the product.

\section{CONCLUSION}

The study finding can be used to improve competitiveness by providing a strategy for the cosmetics industry to achieve co-branding success, especially brands that intend to do cobranding with different sectors, as was done by the two brands mentioned in this research. The prior attitude of invited brands significantly influences subsequent attitudes toward cobranded as well as post attitudes toward host brands (less-known brands). However, the prior attitude of host brands appears weak to influence attitude toward co-branded. This study finds out the mediating role of brand fit to mediate prior attitude (both host and invited) to influence attitude toward co-branded. Hence, the brand fit works to influence consumer perception regarding both brand and co-branded products after they collaborate. Also, post attitude toward host brand appears stronger if mediation contribution of attitude toward cobranded products works to mediate brand. Finally, purchase intention can also be influenced by the consumers if attitudes toward co-branded, post-attitude toward host-brand, and mediation contribution of post-attitude toward host brand appears. Herein, purchase intention of a co-branded product exists if the contribution of three elements such as brand fit, attitude toward co-branded, and post-attitude toward host brand appears.

In addition, it can be an evaluation for both brands to find out consumer perceptions of this strategy. This study also provides on how to choose the right collaboration partner that will benefit co-branded products. Host brands must be careful when choosing invited brands that are equally important. Invited brands that are suitable to be co-branding partners are 
brands that are more familiar than the host brands themselves, have characteristics in both brand and product, preferred by consumers, and most importantly possess a good branding. The main component in co-branding is the fit between host brands. Therefore, a well-known and suitable co-branding partner is needed to give exposure to the co-branded product and provide a spill-over effect for the host brands. In this case, cosmetics and food have different complementary functions. The identity of food brands needed to make consumers familiar with the co-branded product just by looking at the product. Therefore, effective promotion is needed to gain more popularity.

\subsection{Limitation and future research direction}

This study has various limitations that might provide directions for future research. First, research in this study evaluates the concept of co-branding for different types of products that only expresses cosmetic and food brands. The invited brands might have different popularity and influence towards the co-branded products. Therefore, future research has to test in another industry to confirm the co-branding model. In Indonesian context, the application of co-branding strategy also begins to introduce fashion brands that invite food brands in producing remarkable fashion products. From the theoretical point of view, validating brand equity appears important to express the magnitude influence of the invited brand (as a widelyknown brand) to give a spill over effect on the host brand (as a less-known brand).

\section{ACKNOWLEDGEMENTS}

The study could be carried out upon a research grant of Politeknik Negeri Bandung under contract number 105.29/PL1.R7/PG.00.03/2021. We would like to express gratitude to the marketing lecturer collegiate for giving research advice and research assistants who have delivered online questionnaires.

\section{REFERENCES}

Aaker, D., \& Keller, K. (1990). Consumer evaluations of brand extensions. Journal of Marketing, 54(January), 27-41.

Ajzen, I., \& Fishbein, M. (2000). Attitudes and the Attitude-Behavior Relation: Reasoned and Automatic Processes. European Review of Social Psychology, 11(1), 1-33. https://doi.org/10.1080/14792779943000116

Ashton, A. S., \& Scott, N. (2011). Hotel restaurant co-branding: The relationship of perceived brand fit with the intention to purchase. Journal of Vacation Marketing, 17(4), 275-285. https://doi.org/10.1177/1356766711420838

Bengtsson, A., \& Servais, P. (2005). Co-branding on industrial markets. Industrial Marketing $\begin{array}{llll}\text { Management, } 34(7 & \text { SPEC. }\end{array}$ https://doi.org/10.1016/j.indmarman.2005.06.004

Besharat, A. (2010). How co-branding versus brand extensions drive consumers' evaluations of new products: A brand equity approach. Industrial Marketing Management, 39(8), 1240-1249. https://doi.org/10.1016/j.indmarman.2010.02.021 
Böger, D., Kottemann, P., \& Decker, R. (2018). Parent brands' influence on co-brand's perception: a model-based approach. Journal of Product and Brand Management, 27(5), 514-522. https://doi.org/10.1108/JPBM-08-2017-1555

Bollen, K. A., \& Stine, R. (1990). Direct and Indirect Effects: Classical and Bootstrap Estimates of Variability. Sociological Methodology, 20(May), 115. https://doi.org/10.2307/271084

Bouten, L. M., Snelders, D., \& Hultink, E. J. (2011). The impact of fit measures on the consumer evaluation of new co-branded products. Journal of Product Innovation Management, 28(4), 455-469. https://doi.org/10.1111/j.1540-5885.2011.00819.x

Carrillat, F. A., Lafferty, B. A., \& Harris, E. G. (2005). Investigating sponsorship effectiveness: Do less familiar brands have an advantage over more familiar brands in single and multiple sponsorship arrangements? Journal of Brand Management, 13(1), 50-64. https://doi.org/10.1057/palgrave.bm.2540245

Chang, W. L. (2009). Using multi-criteria decision aid to rank and select co-branding partners: From a brand personality perspective. Kybernetes, 38(6), 950-965. https://doi.org/10.1108/03684920910973171

Charry, K., \& Demoulin, N. T. M. (2014). Children's response to co-branded products: The facilitating role of fit. International Journal of Retail and Distribution Management, 42, 1032-1052. https://doi.org/10.1108/IJRDM-08-2013-0166

Chin, W. W. (2010). How to Write Up and Report PLS Analyses. In Handbook of Partial Least Squares (pp. 655-690). https://doi.org/10.1007/978-3-540-32827-8_29

Chin, W. W., Peterson, R. A., \& Brown, S. P. (2008, September). Structural equation modeling in marketing: Some practical reminders. Journal of Marketing Theory and Practice, Vol. 16, pp. 287-298. https://doi.org/10.2753/MTP1069-6679160402

DelVecchio, D., \& Smith, D. C. (2005). Brand-extension price premiums: The effects of perceived fit and extension product category risk. Journal of the Academy of Marketing Science, 33(2), 184-196. https://doi.org/10.1177/0092070304269753

Dickinson, S., \& Heath, T. (2006). A comparison of qualitative and quantitative results concerning evaluations of co-branded offerings. Journal of Brand Management, 13(6), 393-406. https://doi.org/10.1057/palgrave.bm.2540281

Fornell, C., \& Larcker, D. F. (1981). Evaluating structural equation models with unobservable variables and measurement error. Journal of Marketing Research, 39-50.

Fornell, C., \& Larcker, D. F. (1981). Structural Equation Models with Unobservable Variables and Measurement Error: Algebra and Statistics. Journal of Marketing Research, 18(3), 382-388. https://doi.org/10.1177/002224378101800313

Guillet, B. D., \& Tasci, A. D. A. (2010). An exploratory study of multi-cultural views on the Disney-McDonald's alliance. Journal of Travel and Tourism Marketing, 27(1), 82-95. https://doi.org/10.1080/10548400903539740

Hair, Joe F., Ringle, C. M., \& Sarstedt, M. (2011). PLS-SEM: Indeed a silver bullet. Journal of Marketing Theory and Practice, 19(2), 139-152. https://doi.org/10.2753/MTP10696679190202

Hair, Joe F, Sarstedt, M., Ringle, C. M., \& Mena, J. A. (2012). An assessment of the use of partial 
Kania, et al. The Effect of Co-Branding Strategy Elements on Consumer Attitude and Purchase Intention: A Study in Indonesia | 48

least squares structural equation modeling in marketing research. Journal of the Academy of Marketing Science, (40), 414-433. https://doi.org/10.1007/s11747-0110261-6

Hair, Joseph F., Ringle, C. M., \& Sarstedt, M. (2013). Partial Least Squares Structural Equation Modeling: Rigorous Applications, Better Results and Higher Acceptance. Long Range Planning, 46(1-2), 1-12. https://doi.org/10.1016/j.Irp.2013.01.001

Helmig, B., Huber, J.-A., \& Leeflang, P. S. H. (2008). Co-branding: The State of the Art. Schmalenbach Business Review, 60(4), 359-377. https://doi.org/10.1007/bf03396775

Henseler, J., Ringle, C. M., \& Sarstedt, M. (2015). A new criterion for assessing discriminant validity in variance-based structural equation modeling. Journal of the Academy of Marketing Science, 43(1), 115-135. https://doi.org/10.1007/s11747-014-0403-8

Hulland, J. (1999). Use of partial least squares (PLS) in strategic management research: A review of four recent studies. Strategic Management Journal, 20(2), 195-204. https://doi.org/10.1002/(sici)1097-0266(199902)20:2<195::aid-smj13>3.0.co;2-7

Keller, K. L. (1993). Conceptualizing, measuring, managing. Journal of Marketing, 57, 1-22.

Kelly, G., Kopka, U., Küpper, J., \& Moulton, J. (2018). The New Model for Consumer Goods.

Kemenperin. (2019). Kemenperin: Kemenperin Optimistis Pertumbuhan Industri Kosmetik Sentuh 9 Persen. Retrieved March 27, 2021, from https://kemenperin.go.id/artikel/20557/Kemenperin-Optimistis-Pertumbuhan-IndustriKosmetik-Sentuh-9-Persen

Kumar, P. (2005). The impact of cobranding on customer evaluation of brand counterextensions. Journal of Marketing, 69(3), 1-18. https://doi.org/10.1509/jmkg.69.3.1.66358

Lafferty, B. A., Goldsmith, R. E., \& Hult, G. T. M. (2004). The impact of the alliance on the partners: A look at cause-brand alliances. Psychology and Marketing, 21(7), 509-531. https://doi.org/10.1002/mar.20017

Leuthesser, L., Kohli, C., \& Suri, R. (2003). 2+2=5? A framework for using co-branding to leverage a brand. Journal of Brand Management, 11(1), 35-47. https://doi.org/10.1057/palgrave.bm.2540146

Lin, Y. C. (2013). Evaluation of co-branded hotels in the Taiwanese market: The role of brand familiarity and brand fit. International Journal of Contemporary Hospitality Management, 25(3), 346-364. https://doi.org/10.1108/09596111311311017

Oraman, Y., Azabagaoglu, M. O., \& Inan, I. H. (2011). The Firms' Survival and Competition through Global Expansion : A Case Study from Food Industry in FMCG Sector. Procedia Social and Behavioral Sciences, 24, 188-197. https://doi.org/10.1016/j.sbspro.2011.09.021

Rao, A. R., Qu, L., \& Ruekert, R. W. (1999). Signaling Unobservable Product Quality through a Brand Ally. Journal of Marketing Research, 36(2), 258-268. https://doi.org/10.1177/002224379903600209

Rodrigue, C. S., \& Biswas, A. (2004). Brand alliance dependency and exclusivity: An empirical investigation. Journal of Product \& Brand Management, 13(7), 477-487. 


\section{https://doi.org/10.1108/10610420410568417}

Salim Khraim, H. (2011). The Influence of Brand Loyalty on Cosmetics Buying Behavior of UAE Female Consumers. International Journal of Marketing Studies, 3(2), 5389-5398. https://doi.org/10.5539/ijms.v3n2p123

Samadi, M., \& Nejadi, A. Y.-N. (2009). A Survey of The Effect of Consumer's Perceived Risk on Purchase Intention in E-Shopping. Business Intelligence Journal., 2(261-275).

Simonin, B. L., \& Ruth, J. A. (1998). Is a Company Known by the Company It Keeps? Assessing the Spillover Effects of Brand Alliances on Consumer Brand Attitudes. Journal of Marketing Research, 35(1), 30-42. https://doi.org/10.2307/3151928

Stone, C. A., \& Sobel, M. E. (1990). The robustness of estimates of total indirect effects in covariance structure models estimated by maximum. Psychometrika, 55(2), 337-352. https://doi.org/10.1007/BF02295291

Swaminathan, V., Reddy, S. K., \& Dommer, S. L. (2012). Spillover effects of ingredient branded strategies on brand choice: A field study. Marketing Letters, 23(1), 237-251. https://doi.org/10.1007/s11002-011-9150-5

Tasci, A. D. A., \& Denizci Guillet, B. (2011). It affects, it affects not: A quasi-experiment on the transfer effect of co-branding on consumer-based brand equity of hospitality products. International Journal of Hospitality Management, 30(4), 774-782. https://doi.org/10.1016/j.ijhm.2010.12.009

Taylor, A. B., MacKinnon, D. P., \& Tein, J. Y. (2008). Tests of the three-path mediated effect. Organizational Research Methods, 11(2), 241-269. https://doi.org/10.1177/1094428107300344

Tenenhaus, M., Vinzi, V. E., Chatelin, Y. M., \& Lauro, C. (2005). PLS path modeling. Computational Statistics and Data Analysis, 48(1), 159-205. https://doi.org/10.1016/j.csda.2004.03.005

Thompson, K., \& Strutton, D. (2012). Revisiting perceptual fit in co-branding applications. Journal of Product and Brand Management, 21(1), 15-25. https://doi.org/10.1108/10610421211203079

Till, B. D., \& Busler, M. (2000). The match-up hypothesis: Physical attractiveness, expertise, and the role of fit on brand attitude, purchase intent and brand beliefs. Journal of Advertising, 29(3), X-13. https://doi.org/10.1080/00913367.2000.10673613

Trend, H. (2018). Sephora and Museum of Ice Cream are Launching Collaborative Makeup. Retrieved from https://www.trendhunter.com/trends/collaborative-makeup

Vaidyanathan, R., \& Aggarwal, P. (2000). Strategic brand alliances: implications of ingredient branding for national and private label brands. Journal of Product \& Brand Management, 9(4), 214-228. https://doi.org/10.1108/10610420010344013

Vicente-Molina, M. A., Fernández-Sáinz, A., Izagirre-Olaizola, J., Safari, A., Salehzadeh, R., Panahi, R., ... Seewoo, Y. D. (2018). Structural equation modeling in practice: a review and recommended two-step approach. Journal of Cleaner Production, 103(1), 411-423. https://doi.org/10.1108/SRJ-10-2017-0199

Voss, K. E., \& Gammoh, B. S. (2004). Building brands through brand alliances: Does a second 
Kania, et al. The Effect of Co-Branding Strategy Elements on Consumer Attitude and Purchase Intention: A Study in Indonesia | 50

ally help? Marketing Letters, 15(2-3), 147-159. https://doi.org/10.1023/B:MARK.0000047390.01552.a2

Voss, K. E., \& Mohan, M. (2016). Corporate brand effects in brand alliances. Journal of Business Research, 69(10), 4177-4184. https://doi.org/10.1016/j.jbusres.2016.03.007

Wang, S. C., Soesilo, P. K., Zhang, D., \& Anthony Di Benedetto, C. (2012). The impact of luxury brand-retailer co-branding strategy on consumers' evaluation of luxury brand image: The case of Taiwan. In Advances in International Marketing (Vol. 23). https://doi.org/10.1108/S1474-7979(2012)0000023007

Washburn, J. H., Till, B. D., \& Priluck, R. (2000). Co-branding: Brand equity and trial effects. Journal of Consumer Marketing, 17(7), 591-602. https://doi.org/10.1108/07363760010357796

Xiao, N., \& Lee, S. H. (Mark). (2014). Brand identity fit in co-branding: The moderating role of C-B identification and consumer coping. European Journal of Marketing, 48(7-8), 12391254. https://doi.org/10.1108/EJM-02-2012-0075

Yasid, Farhan, F., \& Andriansyah, Y. (2016). Factors affecting Muslim students awareness of halal products in Yogyakarta, Indonesia. International Review of Management and Marketing, 6(4), 27-31.

Yip, P. (2004). Basic concepts of co-branding, with examples from the hospitality industry: could co-branding improve your bottom line? Retrieved from www. hotel-on-line. com/News/PR2005_3rd/Sep05_CoBranding. html

Zhao, X., Lynch, J. G., \& Chen, Q. (2010). Reconsidering Baron and Kenny: Myths and truths about mediation analysis. Journal of Consumer Research, 37(2), 197-206. https://doi.org/10.1086/651257 